\title{
so Angry, so Black
}

\section{Kwene Onotseke Appah}

\begin{abstract}
The constant fear that exists within me, in both academic and non-academic environments, to avoid being the 'angry black woman' has left me paralyzed and feeling invisible. Academia, even academia that is centered on human betterment, is whitewashed. It is disheartening learning about the oppression of the marginalized from a perspective that can only empathize. It is from this place that I anchor the following poem. What the poem lacks in length it makes up for in raw emotion. The burden of being Black and femme for the entirety of one's life is a heavy cross to bear. Black women are continuously failed inside and outside of the Black community. Black women are the foot soldiers, the healers, the tacticians, the martyrs, and yet, their compensation is abuse. In this year of 2020, a devastating decade that has still not given us any peace, I fully accept being the angry Black woman. Unequivocally, unapologetically.
\end{abstract}

\section{Keywords}

black women, black existence, black lives matter, black poetry 
i'll be an "angry black woman" until my voice goes, until my legs go, until my brain goes.

i'll be so angry and so black until there's change.

because we beg, plead, cry, scream, and you don't hear us.

we say no, we say stop,

you don't hear us.

so get ready for our outside voices.

you'll hear us now.

//onotseke 


\section{Author Biography}

Kwene Onotseke Appah is a Nigerian-Canadian immigrant, currently residing on the Treaty 1 lands known as Winnipeg, Manitoba. Appah is a 2nd year graduate student of the Master of Arts program in Sociology at the University of Manitoba. Appah seeks to highlight the multilayered impact of immigration in both their creative work and scholarship by presenting work from a lens that speaks to the intimate, intersectional experiences individuals face. She holds a deep passion for community work that seeks to empower and uplift systemically marginalized groups and is a persistent advocate for initiatives which assist migrants in their respective integration and migration journeys. Appah's masters research addresses identity struggles and conceptions of belonging in the field of immigration and migration; exposing a critical space for inquiry into colonization, immigration policy, nationalism, race, and globalization. In her poetry, she embarks on journeys of understanding, healing, trauma, racism, and the roiling anger they birth. 